\title{
Provo City Library: Building Across a Century
}

Gregory M. Nelson

greg_nelson@byu.edu

Follow this and additional works at: https://scholarsarchive.byu.edu/facpub

Part of the Library and Information Science Commons, and the Mormon Studies Commons

\section{Original Publication Citation}

Gregory M. Nelson. (212) Provo City Library: Building Across a Century, Public Library Quarterly $31: 2,159-18$. This is the author's edition of this work. The final publication can be found at http://dx.doi.org/1.18/1616846.212.68465.

\section{BYU ScholarsArchive Citation}

Nelson, Gregory M., "Provo City Library: Building Across a Century" (2012). Faculty Publications. 73. https://scholarsarchive.byu.edu/facpub/73 accepted for inclusion in Faculty Publications by an authorized administrator of BYU ScholarsArchive. For more information, please contact ellen_amatangelo@byu.edu. 


\title{
Provo City Library: Building Across a Century
}

\author{
Gregory M. Nelson, Ph.D. \\ Brigham Young University \\ 2320 HBLL \\ Provo, Utah 84602 \\ (801) 422-9066 \\ greg_nelson@byu.edu
}

Running Head: History of the Provo City Library 


\begin{abstract}
The public library in Provo City, Utah has undergone significant changes since the founding of the original 1906 building that was funded by Andrew Carnegie. The library has changed according to the needs of the community as it has adapted from its pioneer heritage to a modern service information organization. As it has adapted, however, the Provo Library has maintained its focus on community service with its physical facilities, collection development, community outreach and quality staffing.
\end{abstract}

Key Words: public services, library board, Mormon, Academy Square, collection development, history

Author's biography and contact information:

Gregory M. Nelson, Ph.D., MLIS

Brigham Young University

2320 Harold B. Lee Library

Provo, Utah 84602

greg_nelson@byu.edu

(801) 422-9066

Chemical and Life Science Librarian 


\section{Introduction}

Historical studies of libraries, their progress and regressions, provide insights into the communities they serve and the institutions from which may learn. Hardy (2008) produced a timeline spanning 200 years that illustrated the rich history of Georgia’s public libraries. Wilson (2009) wrote that the Wayne County Public Library of Goldsboro, NC dealt with its collection growth and diversification over a hundred year history by expanding into branch libraries, a story quite different from Provo's struggle with growth. Picco (2008) described the influence the Catholic Church exerted upon the growth of public libraries in Quebec, Canada from the mid1800s to the present time. Like Quebec, Provo’s public library was influenced by a religious organization, the Church of Jesus Christ of Latter-day Saints. Instead of being a threat, however, the Church was a factor in the genesis of the community institution. The public library of Provo is much like many other libraries in the world that have struggled for survival, successfully managed resources and maximized its capabilities.

This history is different from other library histories because particular aspects of Provo library's development occur at different times and in dissimilar contexts than other institutions. There is also the library historian’s problems with library institutional records. Kenneth Harrison (1994) in “Why Library History?” laments the poor record keeping in many organizations and emphasizes the need to keep good historical records not only of society in general, but especially beginning with libraries, our purported repository for society's cultural and literary archives. Records such as annual reports are the basic tools of institutional research. Unfortunately "the historian's job has been made worse by the disappearance from the scene of annual reports. Without them, it is almost impossible to assemble a coherent and detailed history of any association or institution” (Harrison 1994, 10-11). 
This study of the Provo City Library would have been nearly impossible without the records, photographs, and written accounts that were kept by many individuals. Fortunately, the original minutes of the Provo City Library Board from 1905-1943 and 1964-1979 were preserved, making it possible to reconstruct a basic time line for much of the institution's history. The minutes from 1944-1963 were either lost or were not retained. ratifying Harrison's assertion that such a lacuna made Provo's library history from the Library Board's perspective nearly impossible to reconstruct.

For example, from the library's official beginning in 1907 until 1943, the mayor served as a full member of the Library Board. Jumping over the missing time period, the minutes from the 1964 Library Board give no indication that the mayor served as a Board member any longer. Therefore sometime between 1944 and 1963, the mayor stopped attending library board meetings. When and how this event occurred still has to be determined.

Within these limits, therefore, this article provides insights into how the Provo City Library navigated changing times and demographics, as the small western town in the early 1900s became a thriving college town in 2011. The general theme is how the library built upon what was there to make it better.

\section{Building the Building}

The founders of the Provo City library were primarily members of The Church of Jesus Christ of Latter-day Saints (LDS Church or the Mormons) who migrated westward from Illinois in the 1840s to escape religious persecution (Hinckley 1991). They travelled across the Great Plains by foot, covered wagon and handcart to the Utah Territory, settling in the Great Salt Lake Valley in July 1847. In the spring of 1848, thirty families consisting of 150 people traveled approximately fifty miles south of Salt Lake City. This movement followed the counsel of LDS 
Church president Brigham Young to colonize the shores of Utah Lake and establish the Provo region (Jensen 1924).

Life was difficult for these pioneers as they struggled simply to survive, but by 1854 Provo City and the surrounding communities had thriving schools, social activities and healthy commerce (Moffitt 1975). George A. Smith, a prominent church leader, wrote in a letter dated February 28, 1854, that Provo

contains a small Library of 120 volumes, and 200 more have been sent for from the States, which are expected to arrive with the earliest trains in the spring. Efforts are making [sic] to establish similar and other institutions in sundry other small cities. If any of our English friends can contribute music, books, plays, etc. to these institutions they will be gratefully received (Jensen 1924, 133).

In 1885-1886, a circulating library of unknown location was established containing a reading room that was open from 6:00-9:30 in the evenings. This library was associated with local Latter-day Saint churches, but unfortunately only survived for a few years, failing due to a lack of funds (Jensen 1924).

By 1903 a number of Provo citizens formed a library advocacy group called The Book Club. They subsequently suggested that the books collected for the club should be used to form the nucleus of a public library (Jensen 1924; Moffitt 1975). In May of 1905, the Provo City Council appointed a Library Board consisting of twelve members, eight Latter-day Saints, one Congregationalist minister and three others. The Congregationalist and the "others" indicate a broadening religious demographic in Provo at that time (Stauffer 2005). On October 30, 1905 the Provo City Council formally approved the county courthouse basement as the city’s first official 
library with the understanding that it would serve only as a temporary home (Moffitt 1975). The library officially opened its doors on January 2, 1906, with a 1,425 volume collection amassed by a volunteer community effort (Jensen 1924).

The Board of the young public library met to decide how to secure an independent library building. They acted by appointing a committee to contact the well-known philanthropist Andrew Carnegie to seek funds for the construction of a local public library building. Carnegie, an ardent supporter of libraries, between the years 1890 and 1917, provided funding for the construction of 2,509 libraries in the United States at a cost of \$56,162,622.97. Utah was the eventual recipient of 23 of those libraries (Miller 1943).

Carnegie responded to the Provo committee’s query with a positive letter, but required them to lobby for changes in Utah State law so that citizens could collect annual taxes that would support the maintenance of the new library buildings before he would commit funds to build a new library (Jensen 1924; Moffitt 1975). The lobbying effort in the Utah legislature was successful and changes in state law became effective on March 5, 1907, thus paving the way for a Carnegie donation (Moffitt 1975). On April 8, 1907 the library building committee received a letter from Carnegie stating that he would provide $\$ 17,500$ to build a public library in Provo. The offer was contingent upon the city providing the land for the new building and that $\$ 1,750,10 \%$ of Carnegie's initial money, would be provided annually by the city for the library's maintenance (Jensen 1924; Moffitt 1975). Carnegie's offer was gladly accepted.

Land was donated by Jesse Knight, a prominent citizen of the community, and construction commenced in September of 1907 on the northwest corner of Center Street and 100 East Street in central Provo (Writers' Program (Utah) 1942). The construction was completed, library materials transferred and the building furnished nearly 15 months later. The formal 
opening day of the newly dubbed "Provo Public Library” (Provo City Library Board 1905-1915, November 30, 1908) was held on Tuesday, December 1, 1908. Figure 1 is a photograph (circa 1908) of the completed Carnegie building.

The original blueprints of the main floor and basement of the Carnegie-funded library now are located in the John E. Booth Special Collections room of the Provo City Library at Academy Square (Watkins 1907a; Watkins 1907b). The plans identify the location of a bell trap, lecture room, boiler room, "ladies and gents toilets,” a work room, coal bin, portico, director’s room, children's reading room, delivery counter, reading room, stacks room, and a reference alcove (see Appendix $\mathrm{x}$ for the floor plans). From the plans, it is apparent that the library was a closed stacks system with items retrieved by library workers upon request. Further, the basement of the library also contained a Lecture Room, presumably to foster library programs and provide a community space for larger gatherings.

Jensen reports that just seventeen years later, in 1924, the library was in need of more room and the Library Board was "appealing to citizens as well as the city to come to its assistance in supplying the need” $(1924,225)$. Unfortunately, but typically, many public services within the city competed with the library for limited tax dollars, and it was not until 1939, fifteen years later, that financial aid finally arrived in the form of $\$ 59,315$. The city provided $\$ 32,560$ and the Depression-era Public Works Administration provided \$26,640 to remodel and enlarge the existing building, including an update to its furniture and furnishings (Provo City Library Board 1931-1939, March 8, 1939).

The remodeling effort reoriented the original south facing entrance into an east facing entrance and increased the building's internal capacity from the original 5,264 square feet to 
12,500 square feet (Provo City Library Board 1971-1979, June 14, 1973). Figure 2 is a photograph of the remodeled Provo City Library building as it now stands.

In 1941, two years after the renovation, the library held 27,827 volumes, 90 periodical subscriptions, 1,275 pamphlets, and 27 newspaper subscriptions (Writers' Program 1942; Academy History 2011). This collection served approximately 18,071 people according to the 1940 US census (U.S. Bureau of the Census 1942, 1080). At the time of the renovation the Federal Art Center in Utah presented a plan to install an Art Center in the Southeast end of the basement with the condition that they would vacate when requested by the Library Board. The room was also used for meetings provided that the meetings were offered free of charge (Provo City Library Board 1931-1939).

The renovated library served Provo's constituents for many years, but the city’s growth vastly outpaced the library's capability to adequately serve their constituents. The 1977 general plan for Provo indicated that the "American Library Association (ALA) standards recommended a library of at least 42,792 square feet to service the 1977 population. The 1977 general plan called for a new library containing 54,000 square feet to be constructed” (Provo City Community Development Department 1997, 120).

Due to funding problems, however, it was not until 1989 that a 29,000 square foot library was constructed at 425 West Center Street. This building proved to be almost immediately inadequate for housing the library's materials or providing space for library outreach programs and resulted in "the lowest library square footage per capita in Utah" (Provo City Community Development Department 1997, 120). The Library Board of Directors began again to search for another location for the library. In 1996, in conjunction with the Brigham Young Academy Foundation and the Utah Heritage Foundation, the library board made a bid to restore the historic 
Brigham Young Academy building, a local historical monument that long held ties to the community and to education, and transform it into the new home of the Provo City Library (Smoot 2003, 22-23).

In the early years of the Provo City Library, the Brigham Young Academy met many of the educational needs of the community. Dedicated in 1892, the Academy served "as a combination senior high, junior high, and elementary education facility” (Smoot 2003, 16) and was one of the largest education buildings in the Rocky Mountain region, able to accommodate approximately 1,000 students (Academy History 2011).

$\underline{\text { Figure } 3}$ is a photograph of Brigham Young Academy, circa 1896. The Academy as an institution was the precursor to Brigham Young University (BYU). When the BYU Board of Trustees moved the campus to the northern part of Provo, the Academy building was utilized as part of the "lower campus" of the University and also served as a grammar and secondary school until its academic use was discontinued in 1968. The land was sold in 1975 (Smoot 2003). Despite as many as thirteen failed preservation attempts, the building remained vacant for 20 years, becoming dilapidated and an eyesore (Smoot 2003, 8-22). The Academy was slated for demolition in the mid-1990s when the Brigham Young Academy Foundation organized the effort to save the building and use it as a public library. In February of 1997, the Foundation helped to successfully authorize a \$16.8 million library bond issue and the renovation began (Smoot 2003, 20-23). The library was renamed the Provo City Library at Academy Square and was dedicated on September 8, 2001, as a public library and community center for the residents of Provo, a beautiful restoration of the past with an eye to the future (Figure 4).

The renovated building contains a 13,000 square foot, award winning Children’s Library located on the ground floor of the old Academy building. The Mary Stuart Rogers New Wing is 
located adjacent to the East side of the Academy, opposite the Children’s Library. The Rogers New Library Wing serves as a browsing library with adult and young adult material. The second floor of the Rogers New Wing is designated as a "quiet floor" intended for contemplation and studying. It houses the reference collection and the John E. Booth Special Collections room containing material particular to the Provo community. Located outside of Special Collections is an art glass window (Figure 5) entitled "Passages of Light," designed by Mack Magelby and portrayed in glass by Willy Lettig (Smoot 2003, 271-277). The stained glass art depicts a book rising from the hands of a reader into the air and changing into a bird, suggesting the independence and freedom that reading can bring.

The Rogers New Wing is joined to the old Academy building by a beautiful glass conservatory. The upper two floors of the Academy serve as library administration offices and program space, including a 4,000 square foot grand ballroom that at one time housed the Academy's library collection. The Academy, a representation of the past, once again supports the library’s mission to provide material and access to information to all users (Provo City Library at Academy Square 2011).

\section{Building the Collection}

In March 1908, the new Carnegie-built library circulated 1,978 of the 3,000 books available (Provo City Library Board 1905-1915, April 2, 1908). As the library began to establish policies and procedures, book selection was done by the Library Board's Book Committee in conjunction with the Librarian (Provo City Library Board 1905-1915, July 11, 1914). In 1916 “the Librarian suggested that the 'Book Review Digest' be subscribed to as an aid in the selection of books” (Provo City Library Board 1915-1920, August 3, 1916) and the library began to order the ALA fiction list each month starting in 1919 (Provo City Library Board 1915-1920, 
April 8, 1919). Whenever there were excess funds, children's books were purchased, as indicated in the Library Board minutes of December 14, 1923 and December 1, 1932.

It was not until 1938 that the book selection and procurement procedure was changed: “The librarian was given permission to order literature without consulting the book committee each time she places an order” (Provo City Library Board 1931-1939; March 3, 1938). Later, in 1965, the Board minutes reflected that book purchases were "justified on individual merit...[and] the staff continues to improve their analytical abilities and that they strive to be able to recommend those books of superior quality” (Provo City Library Board 1964-1971, January 11, 1965).

In its early years, the library depended not only upon its book budget to secure materials, but upon community donations. Volunteer efforts that provided the library's initial core collection set a standard that would be followed for many years. In 1920 a city wide book drive was conducted by students from six local schools and collected 7,141 books (Provo City Library Board 1920-1930, December 1, 1920). In 1921, 300 pictures were donated by three librarians to start a picture collection (Provo City Library Board 1920-1930, December 14, 1921). In 1928 the library coordinated a book drive again in conjunction with the local schools, resulting in 2,258 donated books of which about 400 were kept and used. The excess books were not used because of poor condition, they were duplicates or they were deaccessioned books the library had previously sold (Provo City Library Board 1920-1930, December 2, 1927).

As the Great Depression began to siphon funds from the library budget, the Library Board suggested that homes and city clubs should be solicited for new books that were needed at the library. This campaign had limited success (Provo City Library Board 1931-1939, October 24, 1932). As the library prepared for the dedication of the renovated Carnegie library on July 
27, 1939 (described in the previous section), there was a big push to garner more books.

Solicitations were made to civic organizations, individuals were cold called from the phone book and book companies were petitioned for donations (Provo City Library Board 1931-1939, November 2, 1939).

This book drive exceeded expectations, and the goal of obtaining 1,000 books was surpassed with a final donation tally of 1,480 books. A list of individuals and book companies that donated are listed in the December 7, 1939, Library Board minutes. The donors included Utah Senator Reed Smoot and members of the First Presidency of the Church of Jesus Christ of Latter-day Saints: Heber J. Grant, David O. McKay and S.O. Bennion (Provo City Library Board 1939-1943). The renovation celebration and book drive was the last community book drive recorded in the Library Board minutes.

Data regarding collection growth in the Provo library was only sparsely reported in the Library Board minutes as follows. The October 11, 1906, letter to Andrew Carnegie stated that there were 2,500 books in the collection, and circulation was about 850 books a month (Provo City Library Board 1905-1915). In March 1908, the library circulated 1,978 books out of the approximately 3,000 books available (Provo City Library Board 1905-1915, April 2, 1908). An April 1908 newspaper clipping reported that 1,696 books were circulated that month (Provo City Library Board 1905-1915, May 1, 1908). The Librarian reported to the Board that $61.5 \%$ of the Young Adult books were fiction and 38.5\% were nonfiction. "The percentage of young adult use for August 1964 and February 1965 was 15.6” (Provo City Library Board 1964-1971, April 12, 1965). From August 1964 to March 1965 the library added 3,183 books and discarded about five percent (Provo City Library Board 1964-1971, April 12, 1965). An inventory in 1966 indicated that the library had 42,000 books, just under half of the 88,000 volumes suggested that a city the 
size of Provo should minimally contain (Provo City Library Board 1964-1971, January 10, 1966). The February 1969 minutes report that in January of that year, 23,553 items were circulated and that those statistics were "by far the highest yet” (Provo City Library Board 19641971, February 10, 1969). McKinnon reported that in 1972 the library had 61,945 total materials (55,238 books) and circulated 346,978 items in that same year (1977, 572). Monthly library circulation for July 1975 reported that the 36,644 items circulated in June 1974 compared to the 42,175 items in June 1975 for a net gain of 5,531 items (Provo City Library Board 1971-1979, July 9, 1975). In 1977 library circulation increased by 31,000 compared to the previous year (Provo City Library Board 1971-1979, October 26, 1977).

Contemporary data regarding the modern library’s collection size were gathered from the Utah State Library Division annual reports for 1997 - 2010. Figure 6 illustrates the growth over the most current fourteen-year period for which data is available. The library experienced strong growth in its collections and the number of items that were circulated between 2002 when the new library was finished through 2005 when the numbers plateaued. This period of growth leveled off in the succeeding four years from 2006 through 2009. Circulation numbers also leveled off between 2005 and 2008, but experienced another burst in 2009 and 2010.

The collection is kept current with an active deaccession program that culls outdated or worn out books. In the last several years, approximately 30,000 new items were brought into the library and roughly an equivalent number of items were weeded from the collection; however, in 2010 there was a net increase in the library’s holdings of 13,211 items. In 2010 the library circulated 1,792,637 items which is very active for a single library without auxiliary branches supporting the population base the size of Provo (Morris 2011). 
The library no longer relies on the community donations for the books and resources in its collection. The majority of library funding for the 2010 fiscal year was obtained from Provo City property taxes with total revenues allocated to the library of $\$ 3,942,106$. Total operating expenditures budgeted for the library during 2010 was \$3,691,683 with: \$ 2,150,170 for personnel and \$309,901 for collections .(Provo City Finance Department 2009).

\section{Building the Community}

The Provo City library has actively reached out to its community since its inception, extending services and providing space for community activities. Two years after the Carnegiebuilt library was completed, the Library Board approved the first children’s hour, sponsored by the Nineteenth Century Club, a local women’s club interested in library services (Provo City Library Board 1905-1915, January 11, 1911). The Children’s Department had a full-time librarian and an assistant librarian available at any one time to assist patrons (Provo City Library Board 1905-1915, February 6, 1913). Responding to patron needs, the Children’s Department expanded its services by opening an hour earlier from 3:00-6:00 pm instead of 4:00-6:00 pm (Provo City Library Board 1915-1920, May 4 1919).

In an effort to improve their new library, the Library Board invited Miss Mary Downy, the State Librarian and a library organizer, to the Provo Library for several weeks in December 1914. She made five suggestions to improve library use, which primarily impacted the youth and are paraphrased here.

1. Do not require a guarantor on youth library cards to those down to Third grade, except for non-residents.

2. Send library cards to adults that are not already registered on the library records.

3. Keep all magazines indexed in the Readers Guide. 
4. Fit the basement as a Children's Department to provide more room on the Main floor for adults.

5. Put duplicate sets of some grade specific books in each school. The teachers would be responsible to track the number of books read in a month and report back to the library. (Provo City Library Board 1905-1915, January 29, 1915).

These suggestions were implemented by the library staff and created a better patron experience.

In 1916, the library gained some notoriety when the Librarian wrote a paper for the state library convention and submitted it to the local newspapers for publication (Provo City Library Board 1915-1920, January 6, 1916). Ever trying to promote more library services, the Library Board authorized Miss Maline Sumner, the Librarian in 1940, to request a 15 minute radio spot once a week from the local radio station (Provo City Library Board 1939-1943, February 1, 1940). Additionally, the library yearly celebrated "National Library Week" in various ways, such as sending out notices, placing banners on the library's front and sponsoring reading contests (Provo City Library Board 1964-1971, April 11, 1966).

Educating children with literature was a chief goal of the Provo librarians. Therefore, they piloted a program to send an employee from the library to the city parks with books "for the use of children who are taking advantage of the recreational program” (Provo City Library Board 1939-1943, July 8, 1943). Mrs. Lucile Thorne was employed to take the books to the parks two afternoons each week for three hours each afternoon (Provo City Library Board 1939-1943, August 3, 1943). The August 3, 1943 Library Board minutes report that “526 books were circulated during four afternoons in July that the books were taken to the parks. The reading of the books, however, was so superficial-in fact, merely looking at the pictures-that Mrs. Cardell recommended that these books be not recorded on the regular circulation records" (Provo City 
Library Board 1939-1943). She felt that counting the park books would be "padding” the circulation numbers. Very small children were the largest user group and almost exclusively at the Pioneer Park.

The library recognized that partnering with local schools would be an effective way to provide services to children. The relationship with the school system bore fruit during the concerted book drives already mentioned. Early in its history, the Provo Public Library loaned books directly to the local schools with the stipulation that the principals and teachers were responsible for the items borrowed (Provo City Library Board 1905-1915, October 8, 1913). This ongoing program lasted at least into the 1920s. The Librarian prepared a list of juvenile books and was authorized to procure them for $\$ 500.00$ to support the program (Provo City Library Board 1920-1930, September 7, 1920). By 1965, the library hosted a summer reading program supported through the schools (Provo City Library Board 1964-1971, May 10, 1965). At the end of one summer reading program, a party was held in which approximately 200 children were present. The Board's minutes recorded that there was "wall to wall children" and the "program was very good” (Provo City Library Board 1964-1971, September 19, 1966). This summer reading program is still active in the library today.

The library also reached out in other less conventional ways to promote library services to various members of the community. They asked the “head of each mechanical dep’t [sic] in the city, and see if they had any suggestions as to what books might be of most use to the men” (Provo City Library Board 1920-1930, October 6, 1920). In the 1960s, an era of heightened social responsibility, the library extended services to the State Mental Hospital in Provo (Provo City Library Board 1964-1971, December 11, 1967), the Eldred Center for senior citizens, the Pittsburgh Des Moines Steel Company and Utah Valley Hospital by providing books on-site 
(“short stories, cartoons”) via a check out slip (Provo City Library Board 1964-1971, July 8, 1968). Further outreach extended library services to the city jail and local juvenile detention home (Provo City Library Board 1964-1971, April 14, 1969). Minutes from a 1970 Library Board meeting reported that a program providing paperback books for short term loan was still ongoing and "very well received" at the hospital and the jail (Provo City Library Board 19641971, June 16, 1970).

Several other community members requested library services at their perceived point of need, such as an area doctor who wanted some books for his waiting room and a local barber who wanted books for people to read while waiting to get their hair cut. The barber reported that only six library books had gone missing from the barbershop while on loan and that approximately $75 \%$ of his customers used the books that were available. Sometimes the pilot projects were less successful, such as when the city Welfare Office reported that 30 out of the 64 books placed in the office had gone missing (Provo City Library Board 1964-1971, January 13, 1969).

Every library is concerned for their collections and as is often the case, similar issues also had to be confronted in the past as they are confronted in the modern libraries of today: overdue books, vandalism and young people loitering by the library at late hours caused considerable angst among the library staff. Delinquent books were often a problem, requiring innovative solutions without raising additional costs. The Library Board directed the Librarian in 1924 to request "the aid of the boy scouts in collecting delinquent books (Provo City Library Board 1920-1930, March 5, 1924). In May 1924, "Scout executive A. A. Anderson stated that the Boy Scout Organization were[sic] willing to collect library books four times during the year providing printed slips stating the name of the book and giving the boys authorized authority 
were supplied by the library” (Provo City Library Board 1920-1930, April 9, 1924). No record is mentioned pertaining to how successful the Boy Scouts were at obtaining overdue books, but it is admirable that the library was willing to try different solutions to address their problems. Another such solution was attempted in the late 1960s when the library instituted Amnesty Week, requesting the return of overdue or missing books without a fine or penalty during which 361 overdue or missing books were returned (Provo City Library Board 1964-1971, May 13, 1968).

In the early years of the library they had to confront an even more difficult situation than missing books- influenza. The deadly influenza epidemic in the early 1900s prompted an entry in the Library Board minutes: “The librarian asked for instruction in regard to receiving books from infected homes and was instructed to write for information as to disinfectants and methods etc. generally used in public libraries” (Provo City Library Board 1905-1915, December 8, 1909). As the world-wide pandemic grew in 1918, the library took a proactive approach to protect staff and patrons, indicated by an entry in the minutes that the "Library was closed on Oct. 11, on account of Spanish Influenza being in the city and remained closed during the remainder of the month” (Provo City Library Board 1915-1920, October 31, 1918).

Questions of policy occasionally made their way into the Library Board minutes. In 1917 the Board discussed an interlibrary loan question. The Library Board received a request from the Price Library, about 65 miles away, to borrow Provo’s “debating material.” The Library Board decided that "we could not make the loan as we needed the material and if granted to one it would have to be to all who wished it [sic]” (Provo City Library Board 1915-1920, January 4, 1917). By 1976 such issues were resolved and interlibrary loan privileges were recognized among the neighboring Provo and Orem communities allowing patrons to borrow items at either 
library with the same library card (Provo City Library Board 1971-1979, January 7, 1976; February 4, 1976).

Issues of who could use the library facilities also became important. One of the early policies enacted by the Library Board was a resolution that the lecture room in the new library would not be used for religious or political purposes (Provo City Library Board 1905-1915, March 2, 1910). The resolution was approved in those early days perhaps to assure non-Latterday Saint members of the community that the library would be an institution available for all of its citizens. Nevertheless, the resolution was disregarded in 1916 when the Democratic Ladies were given permission to use the downstairs of the library for meetings "providing it did not interfere with library work” (Provo City Library Board 1915-1920, September 7, 1916). Moreover, the Library Board received a letter of appreciation from the Methodist, Congregationalist, Baptist, and Episcopal churches “for use of library for their conjoint Sunday night meetings" (Provo City Library Board 1915-1920, October 8, 1918). Further in 1936, the Library Board reversed an old policy of not subscribing to religious materials. At issue was whether the library should subscribe to the Christian Science Monitor. The Library Board responded that "the Librarian was advised to place in the library reading material the public demanded” (Provo City Library Board 1931-1939, December 10, 1936); the newspaper was ordered and made available from that time forward.

Surely there were other instances of policy conflict at the library, but only one made its way into the Library Board minutes in the form of a challenge to a book by Zane Grey. The minutes record that “extracts from Zane Grey’s 'Riders of the Purple Sage’ were read and some discussion followed. Owing to the malicious and erroneous statements made by the author concerning Mormonism, it was voted to withdraw the book from the library shelves.” One board 
member, Mr. Adelin, "wished it recorded on the minutes that he voted against the motion" (Provo City Library Board 1915-1920, April 3, 1917).

Services and programs coupled with the collections available in the Provo library have continued to affect the members of the Provo community. Provo’s mayor, John Curtis, spotlighted the library's 2011 accomplishments in an end-of-year blog post as a series of bullet points (Curtis 2011):

- "Hosted 5,750 patrons at 15 special events and author visits including authors Marcus Zusak, Leif Enger, Christopher Paolini, and Dave Barry.

- Received a grant to host "Manifold Greatness: The Creation and Afterlife of the King James Bible" exhibition from the American Library Association and the National Endowment for the Arts.

- Implemented strategies to fully incorporate ebooks into the library's collection.

- Hosted the Teen Book Fest with 750 attending and four sessions of the popular Fairy Tea with 800 in attendance.

- Installed a new castle themed entrance to the Storyroom in the Children's Services area.

- Checked out over 1,790,000 items; issued 7,400 new library cards; and added over 32,000 new items to the library's collection.

- Created a new bike rack area.”

Commenting on Mayor Curtis's blog regarding the $10^{\text {th }}$ Anniversary dedicating the Provo City Library on Academy Square, Kristi said:

I love that we get to borrow our movies for free. My family doesn't live in Provo and they are all jealous, they have to pay a \$1. I have to agree, there's a lot about Provo to be jealous of and I feel like I am just borrowing Provo, since I am only here for school. But we go to the library often, my little boy has grown up on storytime. It is amazing how big and nice the library is. I am 
a sucker for all things free and the library has so many events, it keeps me busy (2011).

\section{Building the People}

People are the heart and soul of a library. Provo’s first Librarian, Mrs. May Partridge, was hired by the Library Board for \$20.00 per month during the Board’s November 9, 1905 meeting. Mrs. Partridge must have engaged in her library work as a labor of love because adjusting for inflation and taking into account the rural nature of Provo, that $\$ 20$ per month in 1913 (the earliest date available for the calculation) only equals $\$ 458.00$ per month in today’s dollars or $\$ 5,469.00$ per year (http://bls.gov/data/inflation_calculator.htm). After the first three years, the new library became more than one librarian could manage single-handedly, so the Library Board recommended on November 28, 1908 that Miss Helen Smith be hired as an assistant librarian for $\$ 15.00$ per month (Provo City Library Board Provo City Library Board 1905-1915, November 28, 1908). The library’s first apprentice, Miss Ethyl Gadd, was hired by the Library Board on March 2, 1910 (Provo City Library Board 1905-1915). By 1914, Mrs. Partridge had resigned and Miss Hester Bonham took the post of Librarian for \$45 per month. According to the inflation calculator from the Bureau of Labor Statistics, \$45 in 1914 is equivalent to $\$ 1,016.65$ in 2011 for a yearly salary of $\$ 12,199.80$ (http://bls.gov/data/inflation_calculator.htm). This calculator uses the average urban Consumer Price Index for a given calendar year, so even tripling this salary to $\$ 36,599.40$ to account for Provo's rural circumstances, the Librarian's salary was at the low end of the scale by today' standards. The last recorded salary for the Librarian was for Georgia H. Forsyth who was hired for \$140 per month in 1943 (Provo City Library Board 1939-1943, September 1, 1943). 
In 1936 the library had one head Librarian and six staff members. By 1971 (McKinnon 1977) the library had 16 full time employees, though only two had library science degrees. This pair worked in four major departments: Children's, Young Adult, Adult and Reference, and Audio-Visual. In 1971 the library circulated 346,978 items of the total 61,945 items available. In that same year the library acquired 7,410 items and withdrew 2,160. By 1975 the library was serving a community of 63,675 people ” (Provo City Community Development Department 1997, 120) and contained 65,000 books and 125 periodical subscriptions with an annual budget of $\$ 159,000$ (Moffitt 1975, 232). As the number of materials increased over time, so did the need to hire more employees. Sixteen full-time and five part-time staff members managed the collection and served the public in 1975 (Moffitt 1975, 232).

The current organization and staffing of the library is depicted in Figure 7. The Library Director reports to the city's Chief Administrative Officer, who is responsible to the Mayor. Three full-time managers report to the Library Director with subordinate librarians and staff. The 2010 fiscal year budgeted for 51.88 Full Time Equivalents (FTEs) (Provo City Finance Department 2009). Table 1 illustrates the breakdown of the FTEs in regard to their primary work assignment. Many of the library staff were part-time employees who helped the library meet its personnel needs while maintaining its budget and still accomplishing all of the work that must be done in a busy library.

Education was an important part of the library's public service and in-house responsibility. The first Librarian, hired on December 1, 1905, was admonished to go to "Salt Lake to study the Library method used there” (Provo City Library Board 1905-1915, November 28, 1905). Many of the Library Board's minutes record approving the Librarian's request to attend library summer school with travel and tuition support provided by the library. After her 
1912 summer school trip, the Librarian reported that she learned cataloging rules to organize the library’s collection (Provo City Library Board 1905-1915, June 26, 1912).

During 1916, Miss Ellingsworth, a “library worker” presumably from Salt Lake, visited the Provo Library for three weeks to "go over the catalog and make any changes necessary in the classification” (Provo City Library Board 1915-1920, April 6, 1916). She covered three classes of books and reference books, changed some book classifications, and approximately 2000 cards were added to the catalog, "thus making it of much more value to the public by the increased number of subject-headings” (Provo City Library Board 1915-1920, May 4, 1916).

One of the library summer schools most frequented by early Provo librarians was located in Chautauqua, New York (Provo City Library Board 1915-1920, July 2, 1917). It often took six weeks for a round trip training session. In order to save costs and to stay closer to home, the librarians were given leave to attend the Brigham Young University summer school for 12 weeks instead of the Chautauqua, New York school (Minutes1920-1930, May 2, 1923).

The library formally secured a library membership in the American Library Association in 1933 (Provo City Library Board 1931-1939, July 6, 1933) that provided additional training opportunities for the library staff. In fact the Librarian and Assistant Librarian were given paid time to attend the ALA convention in New York City, New York in 1937, one of many future trips (Provo City Library Board 1931-1939, May 6, 1937). The Librarian also attended the Utah state library convention on a yearly basis (Provo City Library Board 1931-1939, October 5, 1939). Membership status within ALA for the library and its workers was underscored when the 1973 Library Board indicated that library funds would cover the membership costs of employees to the ALA and the Utah Library Association (Provo City Library Board 1971-1979, February 6, 1973). 


\section{Conclusion}

The history of the Provo City Library represents growth and episodic change in which caring individuals sought to improve the amount and access to reading and information materials for adults and children. The incomplete evidence that exists suggests that library development was uneven at best, with the institution's development limited many times by lack of funds.

In spite of such retarding factors, the library that began with a few hundred books in 1905 has grown to 294,460 items in 2010 , with an annual circulation of nearly 1.8 million items. In the

$21^{\text {st }}$ century, the Provo Library at Academy Square serves as a place for the community to gather and search, a place where they find both reading materials and information they want and need. Like the art glass on the second floor of the Rogers New Wing (see Figure 5), people are able to open their books and fly on the wings of their own imaginations. 


\section{References}

“Academy history.” Provo City Library at Academy Square. Last modified September 20, 2011. http://www.provolibrary.com/academy-history.

Curtis, John R." 2011 Accomplishments--Library," Provo Insights (blog), December 21, 2011 (3:25 p.m.), http://provomayor.blogspot.com/2011/12/2011-accomplishments-library.html.

Hardy, Elaine. 2008. A timeline of important events in Georgia public library history. Georgia Library Quarterly 45 (2) (Summer 2008): 12-8.

Harrison, Kenneth Cecil. 1994. Why library history? Library Review 43 (8) (08): 9.

Hinckley, Gordon Bitner. 1991. Truth restored a short history of the Church of Jesus Christ of Latter-day Saints. [Salt Lake City]: Church of Jesus Christ of Latter-day Saints.

Jensen, J. Marinus. 1924. History of Provo, Utah. Provo, Utah: Published by the author.

Kristi. September 8, 2011 (4:56 p.m.), comment on John R. Curtis, "Ten Years at the Library," Provo Insights (blog), September 7, 2011 (9:03 p.m.), http://provomayor.blogspot.com/2011/09/ten-years-at-library.html.

McKinnon, Gary F. 1977. The Provo City Library. In Management decisions and organizational policy text, cases, and readings., eds. Francis J. Bridges, Kenneth W. Olm and J. Allison Barnhill. 2d ed. ed., 570-574. Boston: Allyn and Bacon.

Miller, Durand R. 1943. Carnegie grants for library buildings, 1890-1917: A list of library buildings, public and academic, erected with funds provided by Andrew Carnegie and Carnegie Corporation of New York. [New York]: Carnegie Corp.

Moffitt, John Clifton. 1975. The story of Provo, Utah. Provo: Moffitt.

Morris, Donna J. “Utah library statistics”. Utah State Library Division, Department of Community and Economic Development [database online], Last modified March 3, 2011. http://library.utah.gov.erl.lib.byu.edu/programs/development/statistics/index.

Picco, M. A. P. 2008. Quebec's public libraries: An overview of their history and current situation. Public Library Quarterly 27 (2) (04): 139-50.

Provo City Community Development Department. "Provo City general plan.” Last modified August 26, 1997. http://www.provo.org/userfiles/downloads/commdev/genplan1997.pdf.

Provo City Finance Department. “Fiscal 2010 adopted city budget.” Last modified May 5, 2009. http://www.provo.org/finance.rpt.html. 
Provo City Library at Academy Square. Provo City library at Academy Square web site. Last modified December 21 2011. http://www.provolibrary.com/.

Provo City Library Board. 1971-1979. Provo City Library Board Minutes. Provo, Utah.

—. 1964-1971. Provo City Library Board Minutes. Provo, Utah.

—. 1939-1943. Provo City Library Board Minutes. Provo, Utah.

—.1931-1939. Provo City Library Board Minutes. Provo, Utah.

—.1920-1930. Provo City Library Board Minutes. Provo, Utah.

—.1915-1920. Provo City Library Board Minutes. Provo, Utah.

—1905-1915. Provo City Library Board Minutes. Provo, Utah.

Smoot, L. Douglas. 2003. The Miracle at Academy Square. Provo Utah: Brigham Young University Press.

Stauffer, Suzanne M. 2005. Polygamy and the public library: The establishment of public libraries in Utah before 1910. Library Quarterly, Vol.75 (3): 346-70.

U.S. Bureau of the Census. 1942. Sixteenth census of the United States: 1940 population. Vol. 1: Number of Inhabitants. Washington D.C.: U.S. Government Printing Office, http://www2.census.gov/prod2/decennial/documents/33973538v1ch09.pdf.

Watkins, R. "Public Library Basement Floor Plan.” 1907a. Accessed December 22, 2011. http://pac.provo.lib.ut.us/ipac20/ipac.jsp?session=12T8979254J09.209738\&profile=pcl\&so urce $=\sim$ !horizon \&view=subscriptionsummary\&uri=full=3100001 !263933 !0\&ri=3\&aspect =subtab15\&menu=search\&ipp=20\&spp=20\&staffonly=\&term=Public+libraries+--+Utah+-+Provo+--+19081989.\&index=.SW\&uindex=\&aspect=subtab15\&menu=search\&ri=3\#focus.

. Public Library Main Floor Plan. 1907b. Accessed December 22, 2011. http://pac.provo.lib.ut.us/ipac20/ipac.jsp?session=12T8979254J09.209738\&profile=pcl\&so urce $=\sim$ !horizon\&view=subscriptionsummary\&uri=full=3100001 !263932 !1\&ri=5\&aspect =subtab15\&menu=search\&ipp=20\&spp=20\&staffonly=\&term=Public+libraries+--+Utah+-+Provo+--+19081989.\&index=.SW\&uindex=\&aspect $=$ subtab15\&menu=search\&ri=5\#focus.

Wilson, Maegan. 2009. Wayne County Public Library Goldsboro, NC: A brief history. North Carolina Libraries (Online) 67 (2) (Fall): 36-8.

Writers' Program (Utah). 1942. Provo, pioneer Mormon city. American guide series. Portland Oregon: Binfords \& Mort. 


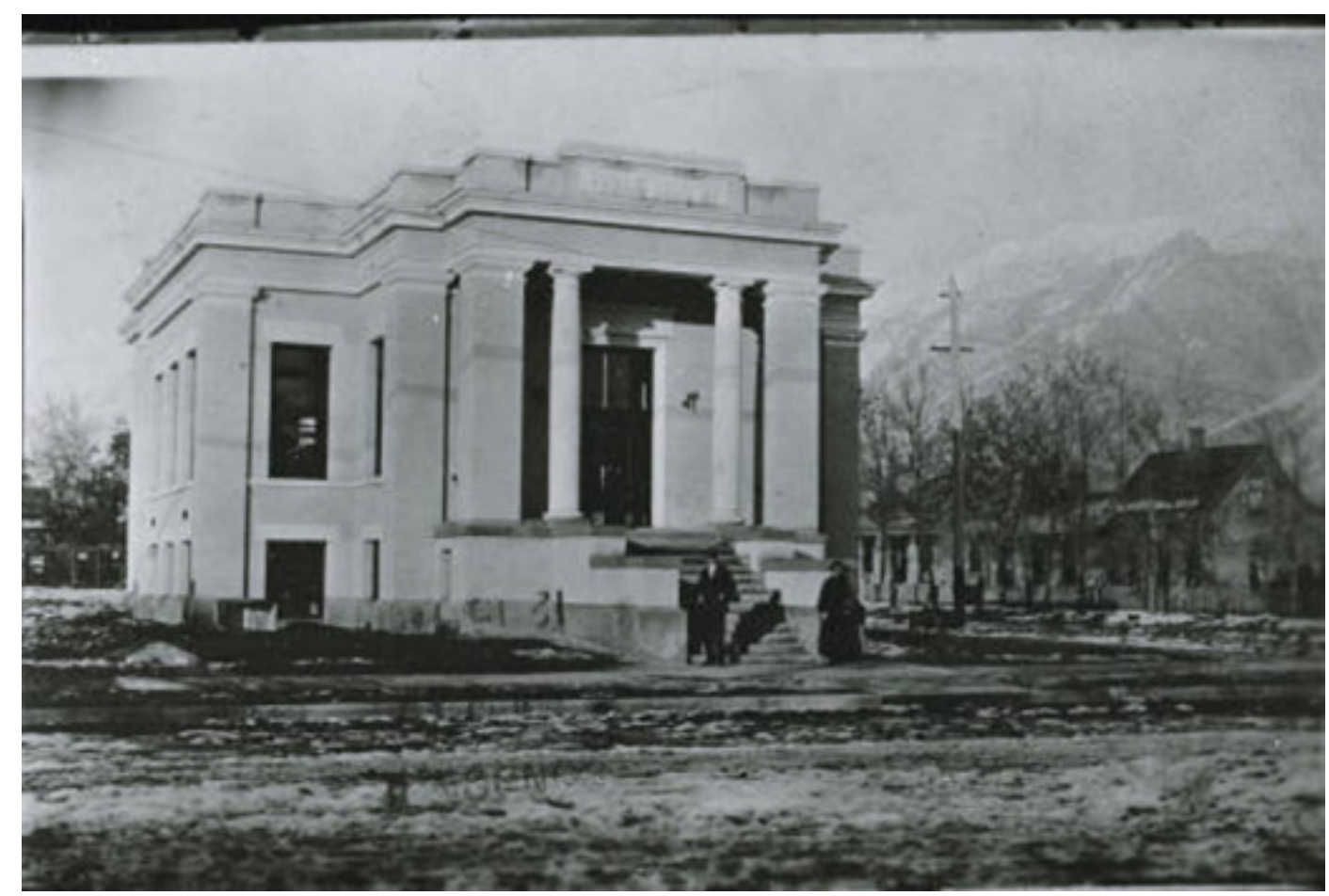

Figure 1. Original Provo City Library. This photograph was taken around 1908 and additional information about the photo can be found at http://contentdm.lib.byu.edu/u?/ProvoPhoto,224 . 


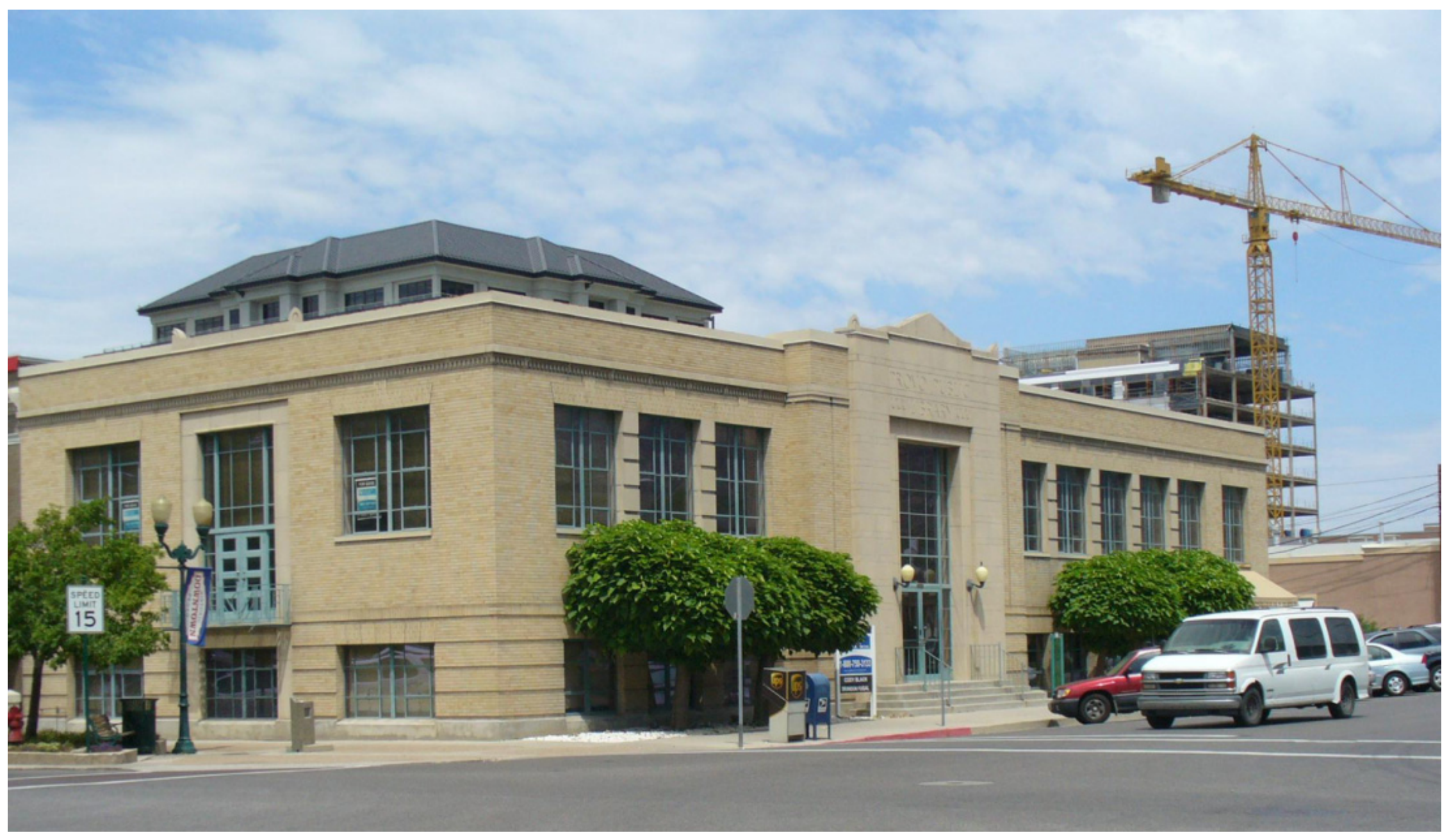

Figure 2. Renovated Provo City Library (Carnegie) building in 2009. 


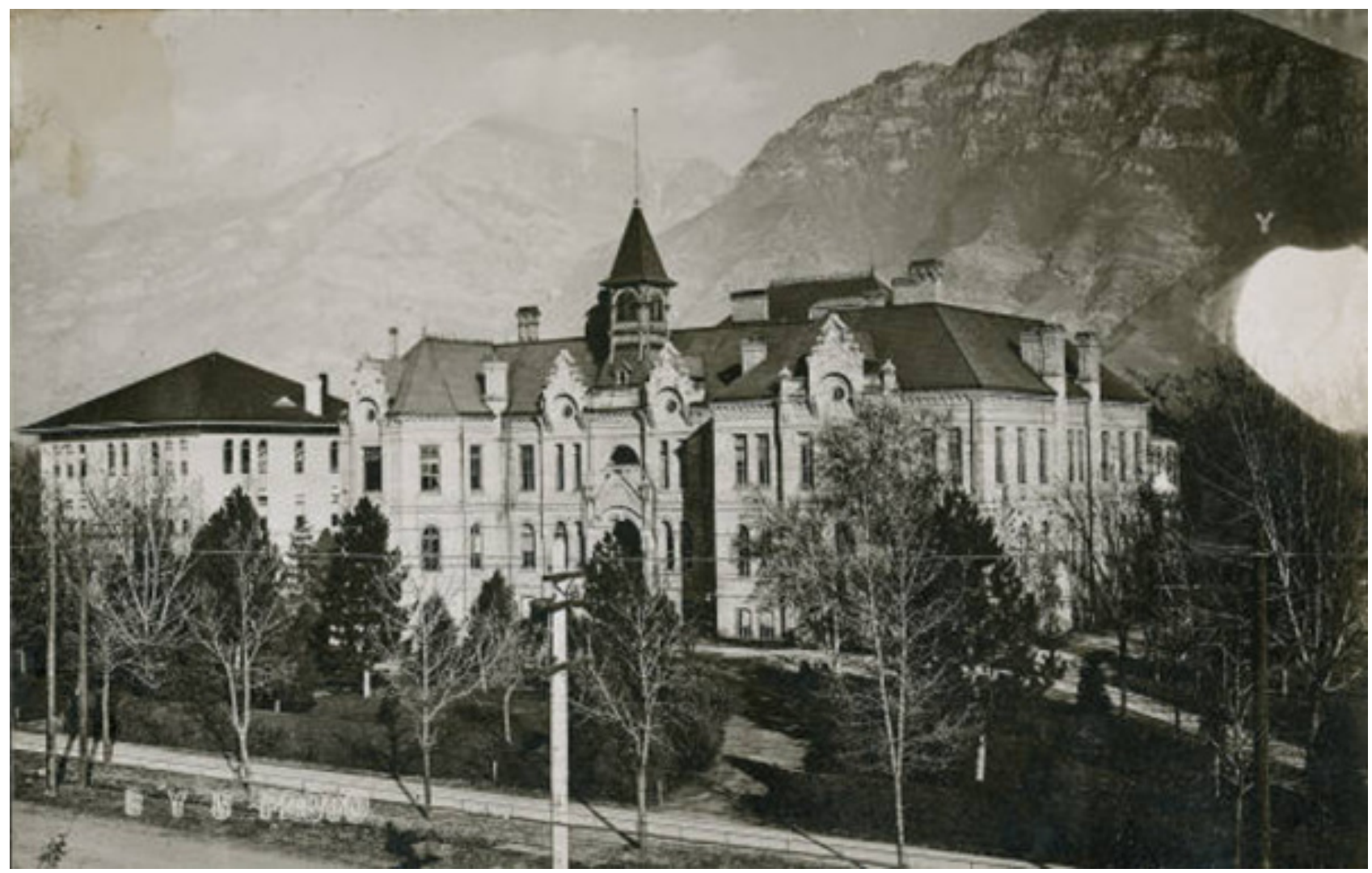

Figure 3. Historic Brigham Young Academy. The photograph was taken circa 1906-1920. More information on the photo and metadata can be found at http://contentdm.lib.byu.edu/u?/ProvoPhoto, 263 


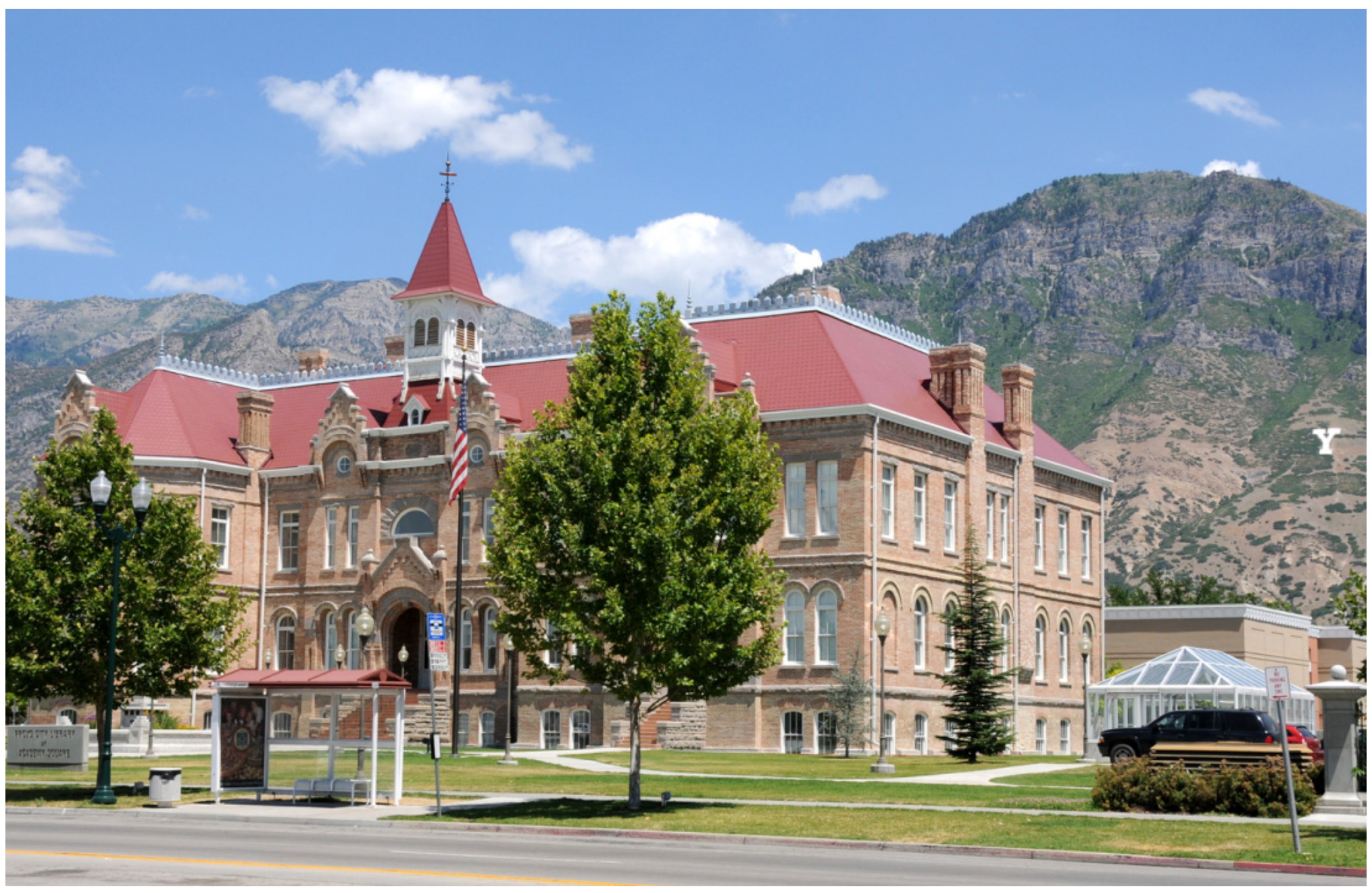

Figure 4. Provo City Library at Academy Square. The restored Brigham Young Academy in 2008 containing the Children's Library in the basement is in the foreground and the Rogers New Wing is partially shown in the background as a lower building behind and right of the Academy building. 


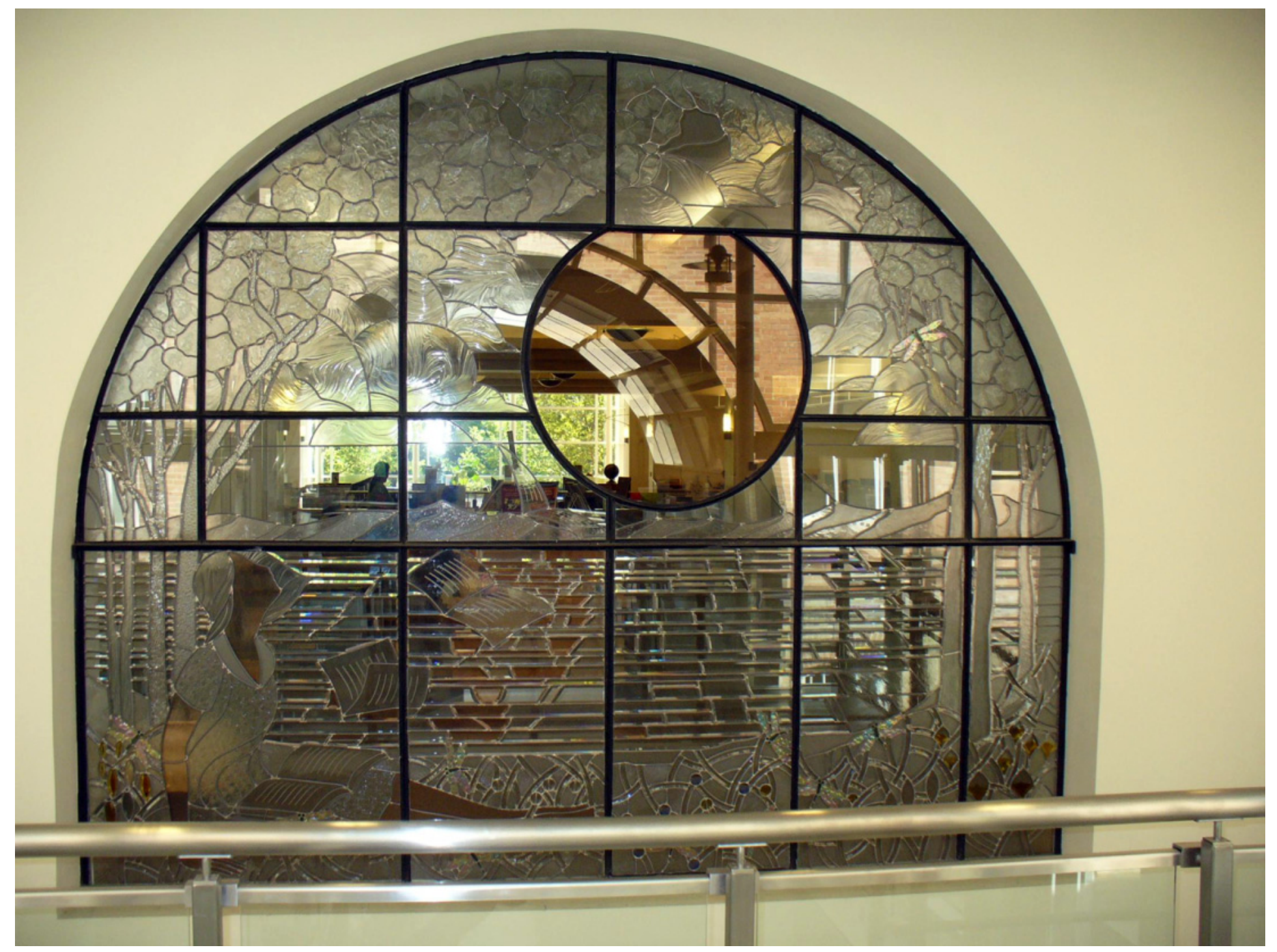

Figure 5. "Passages of Light" looking into the second floor of the Rogers New Wing. 
Figure 6. Holdings and circulation of the Provo City Library from 1997-2010.

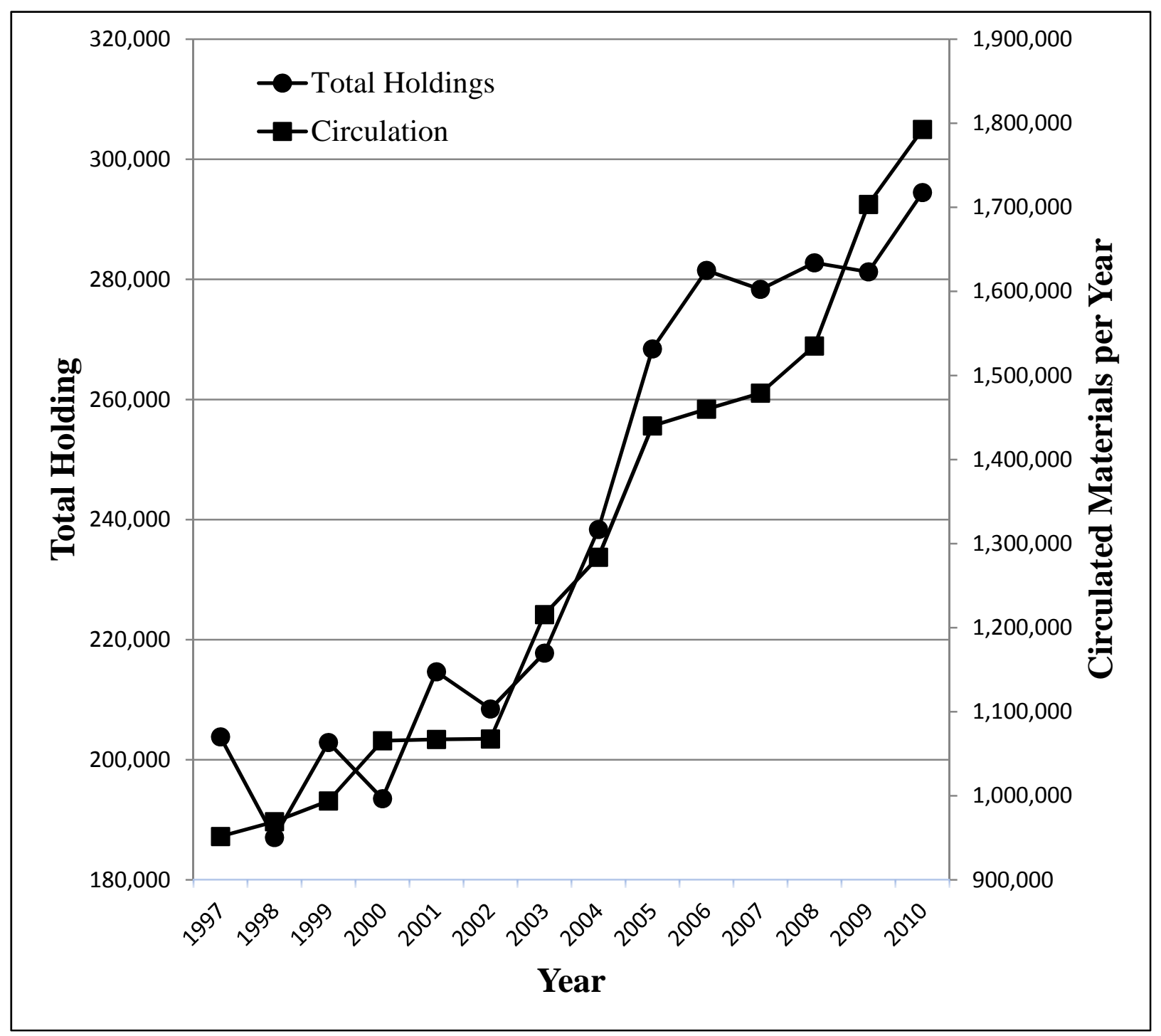


Figure 7. Organizational Chart for the Provo City Library

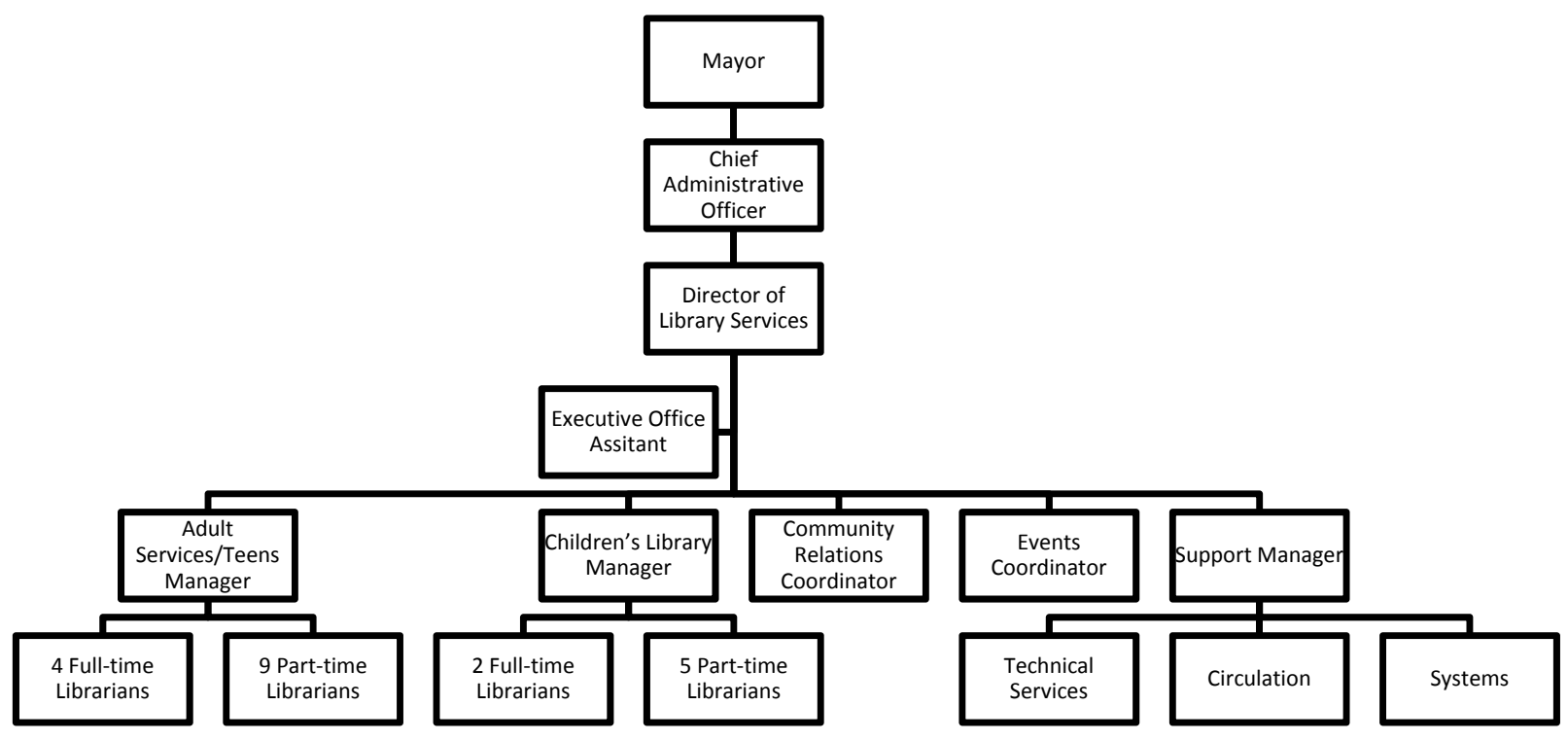


Table 1. Number of Employees Budgeted for the Library in Fiscal year 2010

\begin{tabular}{|ll|}
\hline Section & FTE \\
\hline Administration & 2.50 \\
\hline Circulation & 18.00 \\
\hline Children's Services & 6.13 \\
\hline Systems & 3.00 \\
\hline Adult Services & 10.50 \\
\hline Technical Services & 5.25 \\
\hline Community/Library Events & 5.00 \\
\hline Community Relations & 1.50 \\
\hline \hline Total & 51.88 \\
\hline
\end{tabular}


Appendix 1a. Floor plans for the main level of the original Provo City Library donated by Andrew Carnegie.

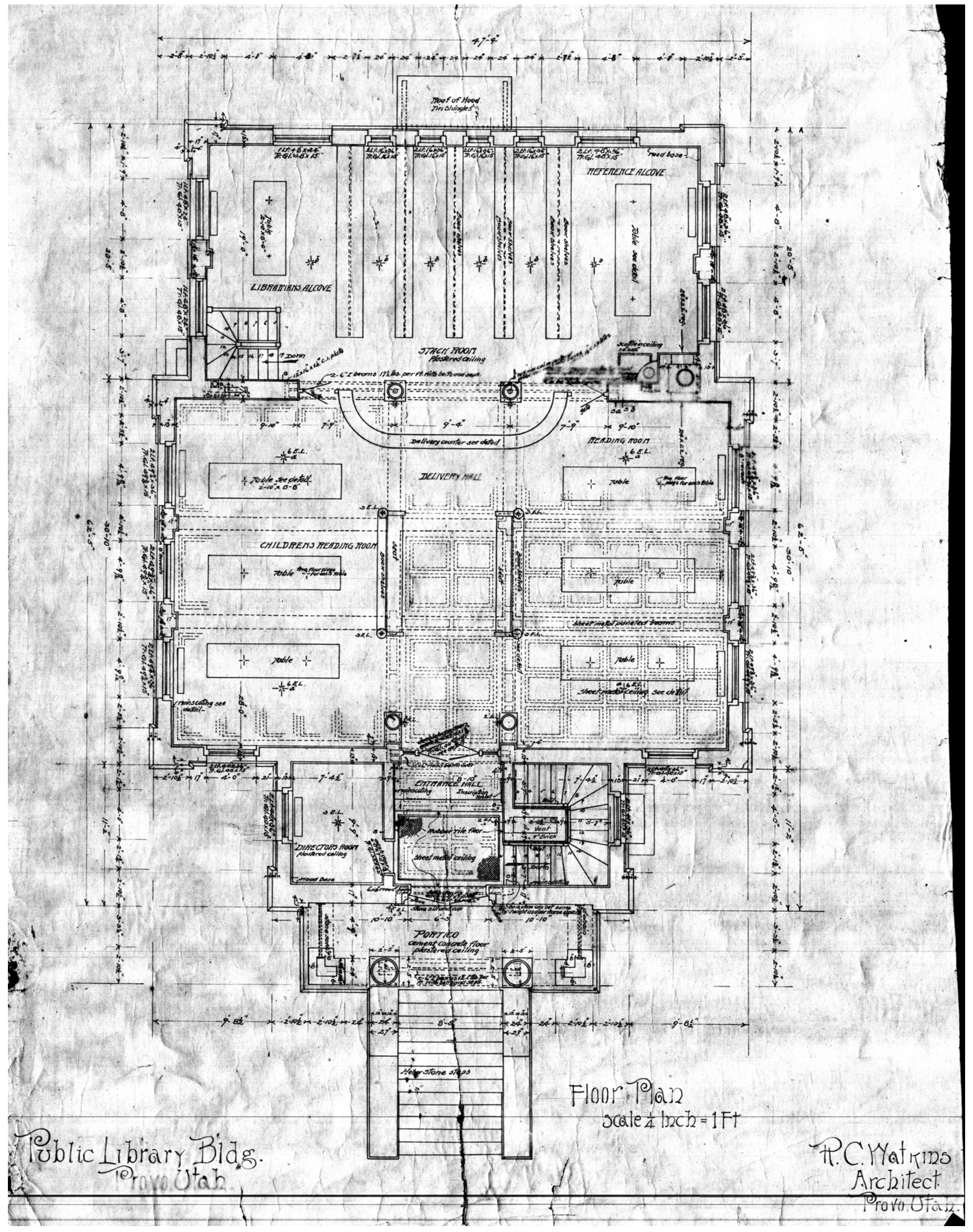


Appendix 1b. Floor plans for the basement level of the original Provo City Library donated by Andrew Carnegie.

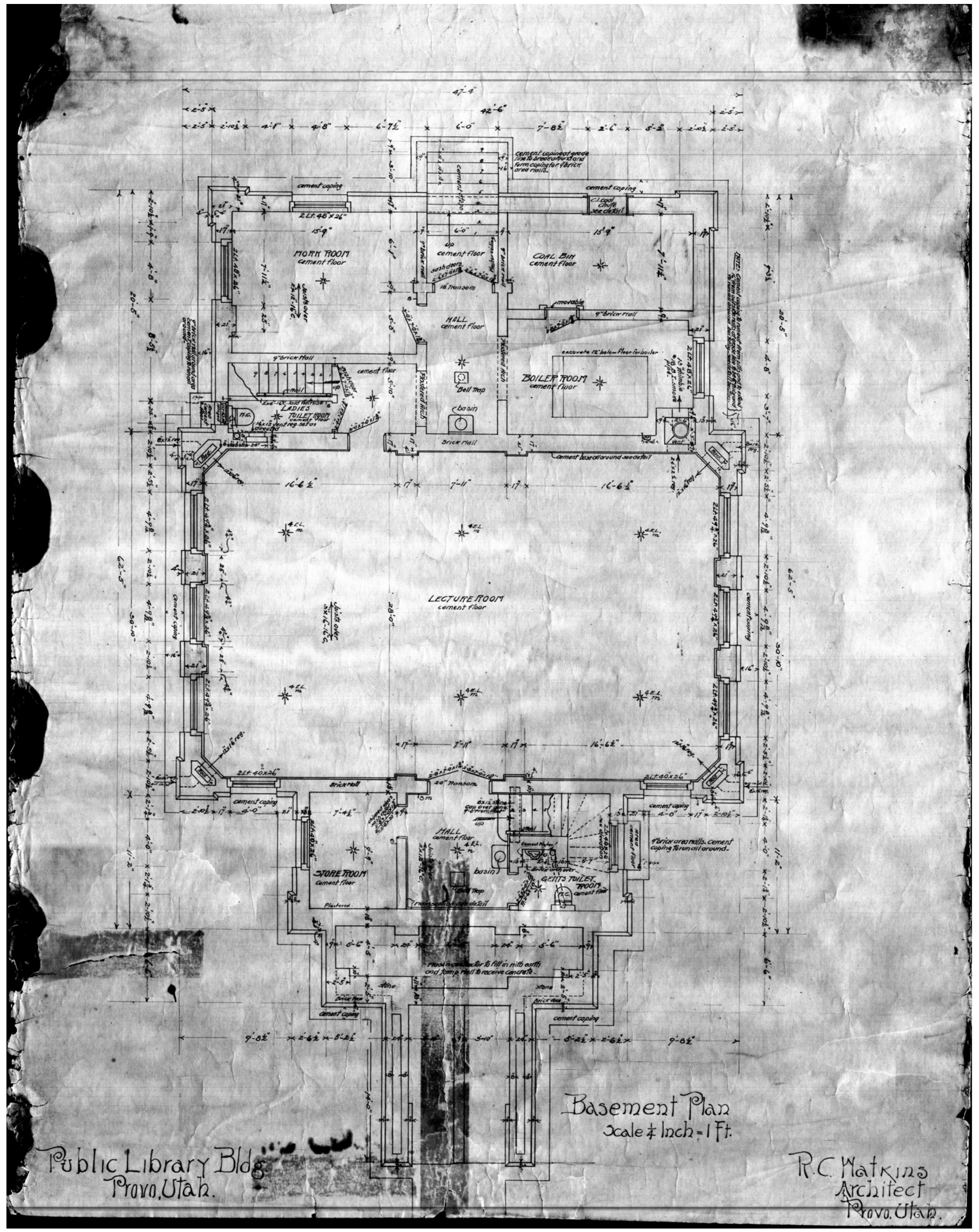




\section{Note}

Original blueprints from the Carnegie-sponsored Provo City Library were generously loaned to the author by the Provo City Library at Academy Square and were scanned on a high quality digital scanner and saved as JPEG files at the Science/Map department within the Harold B. Lee Library at Brigham Young University. The original blue background and white lines of the scanned blueprints were converted to gray scale and inverted so the background was white with black lines for optimal contrast. 